\title{
First record of Trichodina heterodentata (Ciliophora: Trichodinidae) from Arapaima gigas cultivated in Peru
}

\author{
Luis Henostroza MIRANDA ${ }^{1}$ Natalia MARCHIORI ${ }^{2}$, Carmela Rebaza ALFARO ${ }^{1}$, Maurício Laterça MARTINS²
}

\section{ABSTRACT}

This study characterized morphologically Trichodina heterodentata Duncan, 1977 from cultivated fingerlings of "pirarucu" Arapaima gigas in Peru. Body and gill smears were air-dried at room temperature, impregnated with silver nitrate and/or stained with gomori trichromic. Prevalence was 100\%. Trichodina heterodentata was considered a medium-sized trichodinid with mean body diameter of 56.0 $\pm 5.25(47.3-76.0) \mu \mathrm{m}$, denticulate ring $28.21 \pm 2.71(20-34.7) \mu \mathrm{m}$, adhesive disc $45.7 \pm 3.8$ (37.1-57.3) $\mu \mathrm{m}$ diameter and number of denticles of $20.7 \pm 2.6$ (12-24). The present study reports not only the first occurrence of $T$. heterodentata in Peru but also the first record of this trichodinid infesting $A$. gigas. Camparative tables of all reports of T. heterodentata are also presented.

KEYWORDS: pirarucu, trichodinid, morphology.

\section{Primeiro registro de Trichodina heterodentata (Ciliophora: Trichodinidae) em Arapaima gigas cultivados no Peru}

\section{RESUMO}

Este estudo caracterizou morfologicamente Trichodina heterodentata Duncan, 1977 de alevinos de "pirarucu" Arapaima gigas cultivados no Peru. Esfregaços do corpo e brânquias foram secos à temperatura ambiente, impregnados com nitrato de prata e/ ou corados com tricrômico de gômori. A prevalência foi de 100\%. Trichodina heterodentata foi considerada um tricodinídeo de

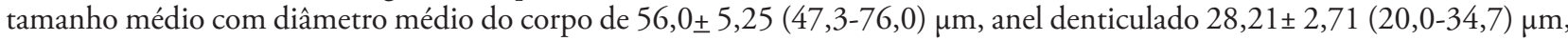
disco adesivo 45,7 $\pm 3,8(37,1-57,3) \mu \mathrm{m}$ de diâmetro e número de dentículos de 20,7 $\pm 2,6(12-24)$. O presente estudo registra não somente a primeira ocorrência de T. heterodentata no Peru mas também o primeiro registro do tricodinídeo parasitando A. gigas. Tabelas comparativas biométricas de todos os registros de T. heterodentata também são apresentados.

PALAVRAS-CHAVE: pirarucu, tricodinídeo, morfologia.

\footnotetext{
1 Institute for Investigation of the Peruvian Amazon (IIAP), National University of Del Santa, Chimbote, Peru - Carretera Federico Basadre Km 12,4, Pucallpa-Peru.

2 AQUOS Laboratory of Aquatic Organisms Health, Aquaculture Department, Federal University of Santa Catarina (UFSC), Rod. Admar Gonzaga 1346, 88040-900, Florianópolis, SC, Brazil. Correspondence to: Maurício L. Martins, Departamento de Aquicultura, CCA, UFSC, Rod. Admar Gonzaga 1346, 88040-900, Florianópolis, SC, Brazil. Phone: 55-4837219923, E-mail: mlaterca@cca.ufsc.br
} 


\section{INTRODUCTION}

Arapaima gigas (Schinz, 1822), better known as "pirarucu" in South America is an endemic species of the Amazonic region. It is a well accepted cultured species due to its rapid growth, great rusticity to handling and high survival rates (Pereira-Filho et al. 2003).

Its parasitic fauna is highlighted by the trichodinids, ciliated protozoans considered as one of the most common parasites in wild and cultivated fish (Basson and Van As 1994). Under suitable environmental conditions these parasites feed on bacteria, algae and particles in water suspension (Eiras 1994). However, under conditions of high stocking density as well as environmental factors, such as increased water temperature and/or high organic matter contents in the water column, the parasites may become pathogenic (Martins et al. 2002; Moraes and Martins 2004). In cultured fish, mortalities can result from heavy infestations causing hyperplasia, epidermis necrosis and destruction of the normal gill architecture (Pearse 1972; McArdle 1984; Khan 2004).

Trichodina heterodentata Duncan, 1977 is a well studied worldwide species. Originally described from Philippine's cultured fishes by Duncan (1977), it has been recorded since then in 20 fish families from Egypt (Al-Rasheid et al. 2000), Australia (Dove and O'Donoghue 2005), India (Asmat 2004), Taiwan (Van As and Basson 1986; Basson and Van As 1994), Southern Africa (Basson et al. 1983; Van As and Basson 1989; Van As and Basson 1992), Israel (Basson et al. 1983), Philippines (Duncan 1977; Albaladejo and Arthur 1989; Bondad-Reantaso and Arthur 1989), Vietnam (Arthur and Te 2006) Venezuela (Basson et al. 1983) and Brazil (Dias et al. 2009; Martins et al. 2010). Up to now, there are no reports of trichodinids identified to species level in Peru.

This study characterized morphologically $T$. heterodentata in tank-reared fingerlings of "pirarucu" A. gigas from Coronel Portillo, Ucayali, Peru. Prevalence and biometrically compared tables of T. heterodentata's reports were also given.

\section{MATERIALS AND METHODS}

Twenty fingerlings of $A$. gigas with $26.63 \pm 1.80 \mathrm{~cm}$ total length and $98.52 \pm 20.88 \mathrm{~g}$ weight were collected from the Peruvian Amazon Research Institute (IIAP) (8²2'31' S; $74^{\circ}$ 34 '35" W) 151 meters above sea level. Fish fingerlings were maintained in concrete tanks $(3.64 \times 0.96 \times 0.44 \mathrm{~m})$ during their first two months of life.

Wet smears of skin and gills were prepared in the field for examination under a microscope. They were air-dried and impregnated with Klein's dry silver method for observation of the adhesive disc as suggested by Lom (1958). Other smears were stained with Gomori trichromic to reveal the nuclear apparatus. The span of the denticle was measured from the tip of blade to the tip of ray as described by Arthur and Lom (1984). The body diameter is the dimension of the adhesive disc plus the border membrane. Wet mounts from the specimens preserved in $5 \%$ formalin solution were studied for the observation of adoral ciliature. All measurements are in micrometers and follow the recommendations of Lom (1958) and Van As and Basson (1989). The description was based on 40 specimens. Arithmetic means \pm standard deviation is followed, in parentheses, by the minimum and maximum values and number of specimens or structures measured. Parasitological indexes such as prevalence were calculated according to Bush et al. (1997). Specimens were deposited in the National Institute of Amazonian Research (INPA), Manaus, AM, Brazil.

To compare our specimens of $T$. heterodentata biometrically with others from previous records, nine characteristics were selected as the most important for morphological comparison, which are: body size, adhesive disc, denticle ring, number of denticles, denticle length, blade length, ray length, central part width and span.

\section{RESULTS AND DISCUSSION}

All examined fish were highly parasitized (100\% prevalence).

\section{Description}

Trichodinidae Claus, 1874

Trichodina Ehrenberg, 1830

Trichodina heterodentata Duncan, 1977

Host: Arapaimidae: Arapaima gigas

Locality: Coronel Portillo, Ucayali - Peru

Microhabitat: Skin, fins and gills

Body: Medium trichodinid with disc-shaped body, diameter 56 $\pm 5.25(47.3-76,40)$

Adoral ciliature 361.8 $\pm 1.17(360-363,5)$

Adhesive disc: slightly concave, $45.7 \pm 3.8(37.1-51.3,40)$; absence of granules in silver-impregnated specimens.

Nuclear apparatus: Horseshoe-shaped macronucleus $42.5 \pm 3(40-46,5)$ of external diameter and $12.0 \pm 1.6(10-14$, $5)$ thickness (Figure 1B). Distance between the terminations of macronucleous is $12.0 \pm 1.63(10-14,5)$.

Denticle ring: $28.21 \pm 2.71(20-34.7,40)$

Number of denticles: $20.7 \pm 2.6(12-24,40)$.

Number of radial pins per denticle: $11.8 \pm 1.6(7-13,15)$

Dimensions of denticle: Length $7.55 \pm 0.62$ (6.31-8.6, 40); blade 4.46 0.59 (3.9-5.5, 40); central part $2.35 \pm 0.28$ $(1.5-3.1,40)$; ray $6.74 \pm 0.81(3.9-7.8,40)$; span $13.19 \pm 1.74$ (7.1-15.7, 40). 
Denticle morphology: The denticles are characterized by wide blade and sickle-shaped provided by apophysis on blade connection with the central part (Figure 1A). The blade fills the space between $y$ and $y-1$ axes. According to figure 2, central part robust ending rounded fitting on the next denticle filling the space between y and y-1 axes. Ray long, robust, slightly directed anteriorly situated between the axes y and $\mathrm{y}-1$, tapering rounded provided by a relatively short apophysis not always evident (Figure 2). Some specimens studied showed inconstant shape and length of ray.

Up until the present, no trichodinid's identification from peruvian fishes have been done and the parasites were ever referred to as Trichodina sp. The present study reports not only the first occurrence of $T$. heterodentata in Peru but also the first record of this trichodinid infesting $A$. gigas. Araújo et al. (2009) reported the presence of an unidentified trichodinid in Brazilian farmed fingerlings of $A$. gigas, but with lower indexes of mean intensity of infection when compared to the present work.

Reared fishes are frequently exposed to stressful conditions such as high stocking density, high organic matter contents and low oxygen concentration. According to Moraes and Martins (2004) in Brazilian aquaculture these factors are responsible for a decrease in fish resistance. On this view, the parasitic fauna find an adequate environment to reproduce. In fact, as here observed, the number of trichodinids was considered extremely high.

Apart from denticle number (Figure 3D) and dimensions of denticle (Figure 3E-F), it can be observed a great standard deviation in the measurements of the body size, adhesive disc and denticle ring among the other $T$. heterodentata characterizations (Figure $3 \mathrm{~A}-\mathrm{C}$ ). Trichodina heterodentata is known to reveal considerable variation in denticle shape,

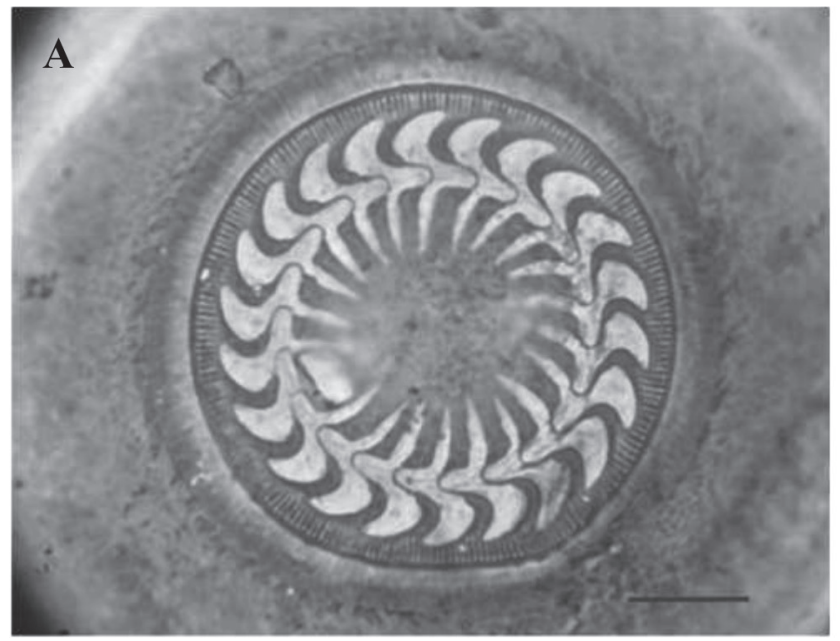

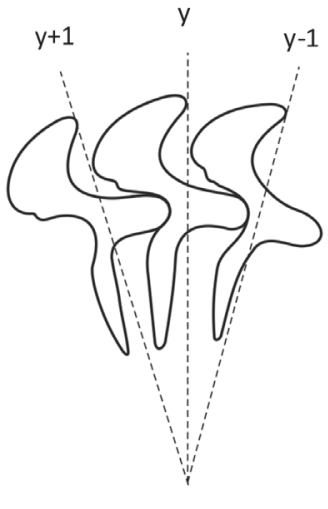

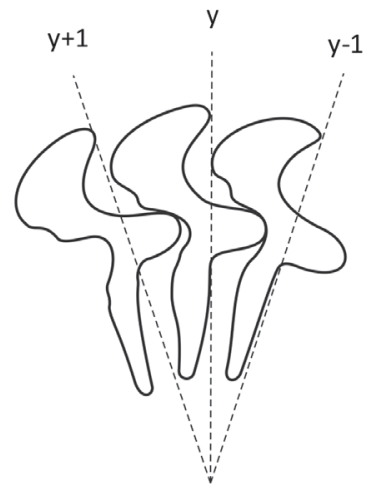

Figure 2 - Diagrammatic drawings showing variation on the shape of the ray of Trichodina heterodentata.

especially in relation to the shape of the ray (Basson and Van As 1994). It was verified in this work that in some specimens the ray was somewhat thicker than in others. Its size was also variable, as reported in other studies and constitutes an important diagnostic character (Van As and Basson 1989; Kruger et al. 1993; Dove and O'Donoghue 2005; Dias et al. 2009) (Figure 3B).

Dove and O'Donoghue (2005) also recorded high amplitude values of $T$. heterodentata adhesive disc among the studied specimens. This data may be positively correlated with ray's length variation, since in almost all published works it presented greater variation than its blade (Figure 3B).

Trichodina heterodentata is regarded as a species with a host preference toward cichlids, but which is also able to utilize other available hosts (Van As and Basson 1994). So far, it has been reported in more than 50 fish species worldwide, cichlids and cyprinids being the most parasitized groups. Eleotridae and Poeciliidae also holds a high number of parasitized

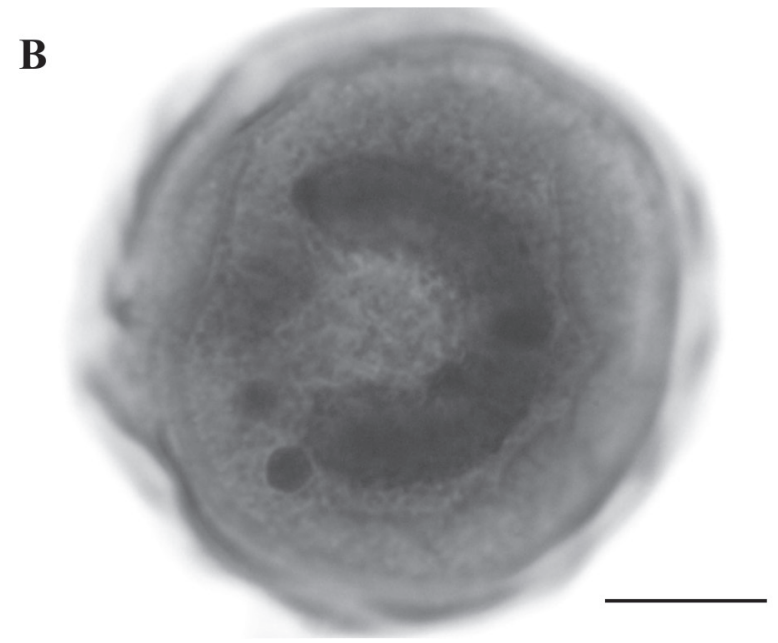

Figure 1 - A. Photomicrographs of Trichodina heterodentata. A. Silver impregnated adhesive disc. B. Gomori trichromic stained macronucleus and micronucleus. Bars: $10 \mu \mathrm{m}$ 
A

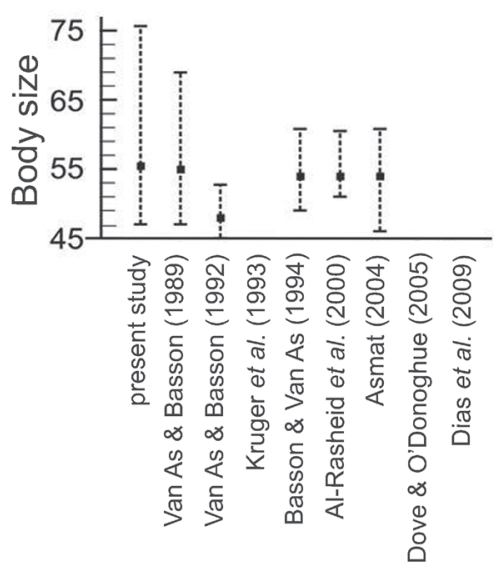

C

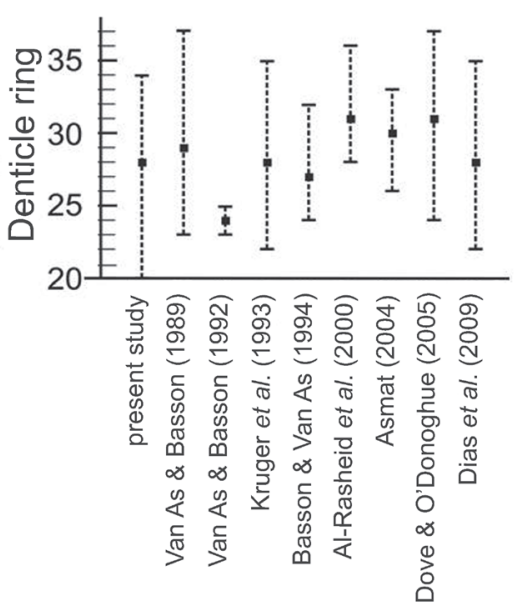

E

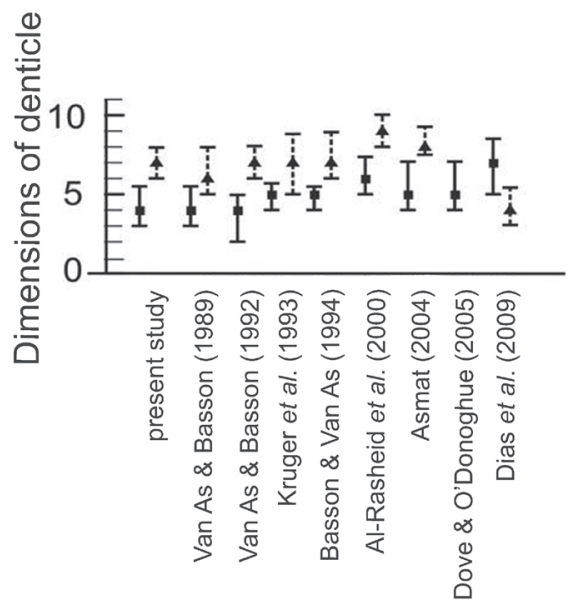

B

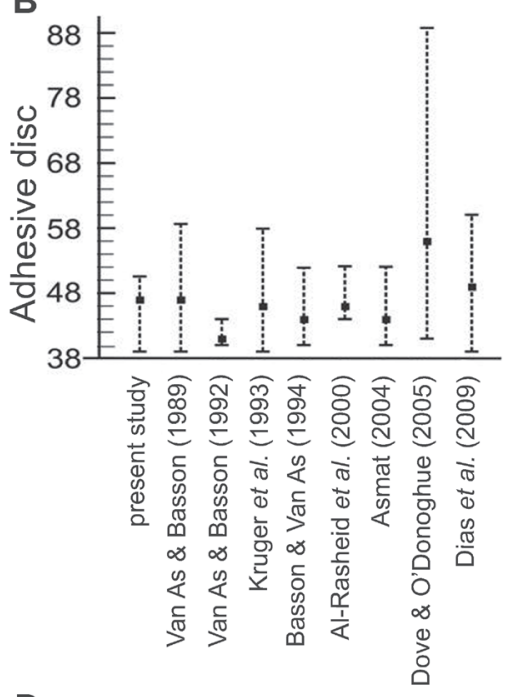

D

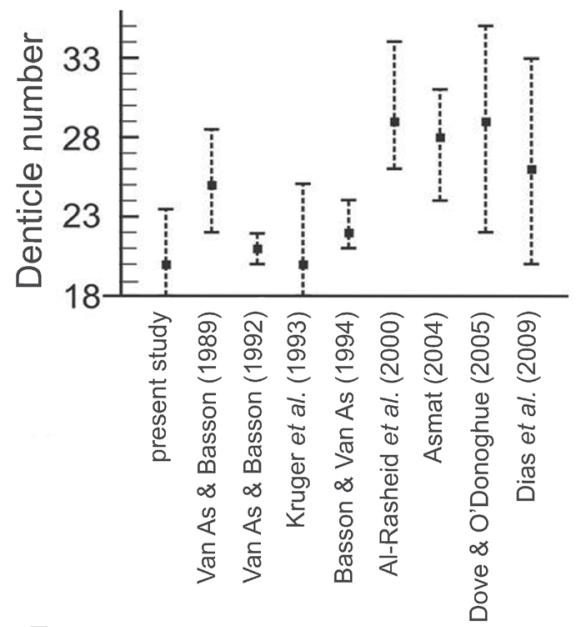

$\mathbf{F}$

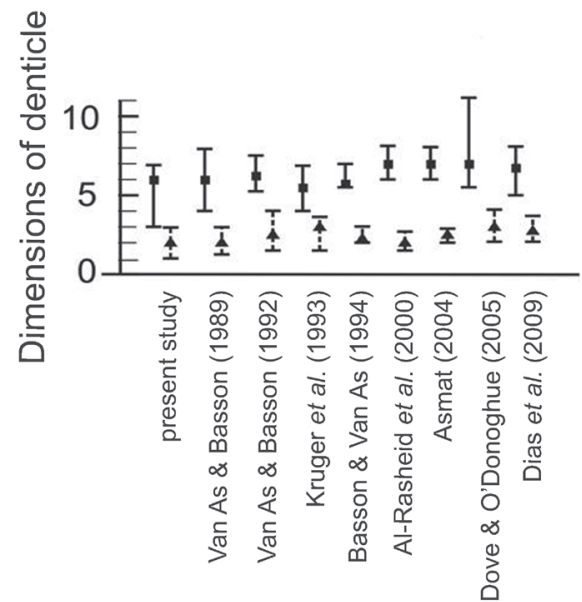

Figure 3 - Morphological variation in dimensions of Trichodina heterodentata. A-body size; B-adhesive disc; C-denticle ring; D-denticle number; E- denticle length (dashed line), blade length (straight line); F- central part width (dashed line), ray length (straight line). 
species, which leads the authors to hypothesize that maybe there isn't a fish host preference and such available data are merely a reflect of what has already been studied. More studies covering a higher number of fish families are necessary to elucidate this question.

By analyzing trichodinid standard deviation of the present study with those characterized by other authors, we can assume that this method of comparison is recommended. By the fact that the dimensions of denticle showed closely variation, the authors suggest to researchers the comparison or analysis of adhesive disc, denticle ring and denticle number in their species comparison. Both these three characteristics and the proposed analysis of axis y denticle position of Van As and Basson (1989) might be necessary to observe variation among the trichodinid species. It must be emphasized that the suggested method was based on $T$. heterodentata, a species that present significant differences of its measurements. The authors can assume that in the other species a graphic view comparison could facilitate a correct comparison.

\section{ACKNOWLEDGEMENTS}

The authors thank CNPq (National Council of Scientific and Technological Development) for grant to ML Martins and CAPES for financial support to NC Marchiori.

\section{REFERENCES}

Albaladejo, J.D.; Arthur, J.R. 1989. Some trichodinids (Protozoa: Ciliophora: Peritrichida) from freshwater fishes imported into the Philippines. Asian Fisheries Science, 3: 1-25.

Al-Rasheid, K.A.S.; Ali, M.A.; Saakran, T.; Baki, A.A.A.; Ghaffar, F.A.A. 2000. Trichodinid ectoparasites (Ciliophora: Peritrichida) of some River Nile fish, Egypt. Parasitology International, 49: 131-137.

Araújo, C.S.O.; Gomes, A.L.; Tavares-Dias, M.; Andrade, S.M.S.; Belém-Costa, A.; Borges, J.T.; Queiroz, M.N.; Barbosa, M. 2009. Parasitic infections in Pirarucu fry, Arapaima gigas Schinz, 1822 (Arapaimatidae) kept in a semi-intensive fish farm in Central Amazon, Brasil. Veterinarski Arhiv, 79: 499-507.

Arthur, J.R.; Lom, J. 1984. Trichodinid protozoa (Ciliophora: Peritrichida) from freshwater fishes of Rybinsk Reservoir, USSR. Journal of Protozoology, 31: 82-91.

Arthur, J.R.; Te, B.Q. 2006. Checklist of the parasites of fishes of Viet Nam. FAO Fisheries Technical Paper, Rome, FAO, no.369/2, p. 14.

Asmat, G.S.M. 2004. First record of Trichodina diaptomi (Dogiel, 1940) Basson and Van As, 1991, T. heterodentata Duncan, 1977 and T. oligocotti (Lom, 1970) (Ciliophora: Trichodinidae) from Indian fishes. Pakistan Journal of Biologial Sciences, 7: 2066-2071.
Basson, L.; Van As, J.G. 1994. Trichodinid ectoparasites (Ciliophora: Peritrichida) of wild and cultured freshwater fishes in Taiwan, with notes on their origin. Systematic Parasitology, 28: 197-222.

Basson, L.; Van As, J.G.; Paperna, I. 1983. Trichodinid ectoparasites of cichlid and cyprinid fishes in South Africa and Israel. Systematic Parasitology, 5: 245-257.

Bondad-Reantaso, M.G.; Arthur, J.R. 1989. Trichodinids (Protozoa: Ciliophora: Peritrichida) of Nile Tilapia (Oreochromis niloticus) in the Philippines. Asian Fisheries Science, 3: 27-44.

Bush, A.O.; Lafferty, K.D.; Lotz, J.M.; Shostak, W. 1997. Parasitology meets ecology on its own terms: Margolis et al. revisited. Journal of Parasitology, 83: 575-583.

Dias, R.J.P.; Fernandes, N.M.; Sartini, B.; Silva-Neto, I.D.; D'Agosto, M. 2009. Occurrence of Trichodina heterodentata (Ciliophora: Trichodinidae) infesting tadpoles of Rhinella pombali (Anura: Bufonidae) in the Neotropical area. Parasitology International, 58: 471-474.

Dove, A.D.M.; O’Donoghue, J. 2005. Trichodinids (Ciliophora: Trichodinidae) from native and exotic australian freshwater fishes. Acta Protozoologica, 44: 51-60.

Duncan, B.L. 1977. Urceolariid ciliates, including three new species, from cultured Philippines fishes. Transactions of the American Microscopical Society, 96: 76-81.

Eiras, J. 1994. Elementos de Ictioparasitologia. Fundação Eng. Antonio de Almeida, Porto, PT. 339 pp.

Khan, R.A. 2004. Disease outbreaks and mass mortality in cultured Atlantic cod, Gadus morrhua L., associated with Trichodina murmanica (Ciliophora). Journal of Fish Diseases, 27: 181-184.

Kruger, J.; Van As, J.G.; Basson, L. 1993. Trichodina heterodentata Duncan, 1977 (Ciliophora: Peritrichida), an ectoparasite on larvae of the African clawed toad Xenopus laevis laevis (Daudin, 1802). Acta Protozoologica, 32: 255-259.

Lom, J. 1958. A contribution to the systematics and morphology of endoparasitic trichodinids from amphibians, with a proposal of uniform specific characteristics. Journal of Protozoology, 5: 251-263.

Martins, M.L.; Onaka, E.M.; Moraes, F.R.; Bozzo, F.R.; Paiva, A.M.F.C.; Gonçalves, A. 2002. Recent studies on parasitic infections of freshwater cultivated fish in the State of São Paulo, Brazil. Acta Scientiarum Biological Sciences, 24: 981-985.

Martins, M.L.; Marchiori, N.C.; Nunes, G.; Rodrigues, M.P. 2010. First record of Trichodina heterodentata (Ciliophora: Trichodinidae) from channel catfish, Ictalurus punctatus cultivated in Brazil. Brazilian Journal of Biology, 70: 637-644.

McArdle, J.F. 1984. Trichodina as a cause of mortalities in cage reared rainbow trout (Salmo gairdneri) and salmon (Salmo salar). Bulletin of the European Fish Pathologists, 4: 3-6.

Moraes, F.R.; Martins, M.L. 2004. Predisposing conditions and principal diseases of intensive fish farming teleosts, p. 343-383. In: Cyrino, J.E.P.; Urbinatti, E.C.; Fracalossi, D.M.; Castagnolli, N. (Eds.), Especial topics in intensive freshwater fish culture in the Tropics. São Paulo: TecArt,. 
Pearse, L. 1972. A note on a marine trichodinid ciliate parasite on the skin of captive flatfish. Aquaculture, 1: 261-266.

Pereira-Filho, M.; Cavero, B.A.S.; Roubach, R.; Ituassú, D.R.; Grandra, A.L.; Crescêncio, R. 2003. Cultivo do pirarucu (Arapaima gigas) em viveiro escavado. Acta Amazonica, 33: 715-718.

Van As, J.G.; Basson, L. 1986. Trichodinids (Ciliophora: Peritricha) ectoparasites of cultured cichlids from Taiwan. Bulletin of the Institute of Zoology, Academia Sinica, 25: 135-139.
Van As, J.G.; Basson, L. 1989. A further contribution to the taxonomy of the Trichodinidae (Ciliophora: Peritrichia) and a review of the taxonomic status of some fish ectoparasitic trichodinids. Systematic Parasitology, 14: 157-179.

Van As, J.G.; Basson, L. 1992. Trichodinid ectoparasites (Ciliophora: Peritrichida) of freshwater fishes of the Zambesi River System, with a reappraisal of host specificity. Systematic Parasitology, 22: 81-109.

Recebido em: 17/03/2011

Aceito em: 10/06/2011 